\title{
Nitrate reduction activity determined with a continuous flow-through system in sediments from a subantarctic coastal environment
}

\author{
Actividad nitrato reductora determinada con un sistema de flujo continuo en \\ sedimentos de un ambiente costero subantártico
}

\begin{abstract}
Américo I. Torres ${ }^{1}$, Mónica N. Gil ${ }^{1}$ and José Luis Esteves ${ }^{1}$
${ }^{1}$ Laboratorio de Oceanografía Química y Contaminación de Aguas, Centro Nacional Patagónico, (CONICET), Boulevard Brown 2915, (9120) Puerto Madryn, Chubut, Argentina. americo@cenpat.edu.ar
\end{abstract}

\begin{abstract}
Resumen.- La sedimentación y acumulación de detritos orgánicos autóctonos y alóctonos en el sedimento marino, favorece la actividad microbiana, consume el oxígeno disuelto y disminuye el potencial de óxido-reducción. En condiciones anaeróbicas otros aceptores de electrones son utilizados en los procesos de oxidación de la materia orgánica. La reducción de nitrato es un proceso importante que está relacionado con el ciclo del nitrógeno y la oxidación. El objetivo de este estudio fue estimar la actividad nitrato reductora en sedimentos de la Bahía Encerrada, la cual se encuentra sometida a una fuerte influencia antropogénica desde la ciudad de Ushuaia. Las muestras de sedimento fueron tomadas en septiembre de 2007 con draga Van-Veen y almacenadas en oscuridad. La actividad nitrato reductora fue estimada in vitro mediante un sistema de flujo continuo. La tasa de incorporación de nitrato se aproximó a una cinética del tipo Michaelis-Menten donde los valores de $K_{m}$ y $V_{\max }$ fueron $1028 \mu \mathrm{M}$ y $2,7 \mu \mathrm{mol} \mathrm{g}^{-1} \mathrm{~h}^{-1}$, respectivamente. Se concluye que el nitrato es utilizado preponderantemente como aceptor final de electrones durante la oxidación de compuestos orgánicos en el sedimento de Bahía Encerrada.
\end{abstract}

Palabras clave: Nitrato, amonio, reactor, denitrificación, Patagonia argentina

\begin{abstract}
Sedimentation and accumulation of autochthonous and allochthonous organic detritus in marine sediments stimulate microbial activity, consume dissolved oxygen and decrease redox potential. In anaerobic conditions, other electron acceptors are utilized in organic matter oxidation process. Nitrate reduction is an important pathway which is related with nitrogen cycling and oxidation. The purpose of this study was to assess the nitrate reduction activity in sediments of Encerrada Bay, which is under a strong anthropogenic influence from Ushuaia city. Sediment samples were taken in September 2007 with a Van-Veen dredge and stored in darkness. Nitrate reduction activity was estimated in vitro using continuous flow-through system. Nitrate uptake rate followed a Michaelis-Menten kinetic where $K_{m}$ and $V_{\max }$ values were equal to $1028 \mu \mathrm{M}$ and $2.7 \mu \mathrm{mol} \mathrm{g}^{-1} \mathrm{~h}^{-1}$, respectively. We concluded that nitrate is used principally as terminal electron acceptor during the oxidation of organic compounds in sediment of Encerrada Bay.
\end{abstract}

Key words: Nitrate, ammonium, reactor, denitrification, Argentinean Patagonia

\section{INTRODUCTION}

Nitrogen is the most abundant element in the terrestrial atmosphere and constitutes an essential nutrient to organisms since it is fundamental to the structures of biomolecules and biochemical processes that define life (Camargo \& Alonso 2006, Francis et al. 2007). The nitrogen in the water column of a coastal system subjected to anthropogenic impact can come principally from two different inputs: external discharges (such as domestic and industrial sewages or agriculture activities) and benthic recycling. Independently of its origin, nitrogen transformations in sediments significantly contribute in the trophic state as well as in the biogeochemical cycling of coastal environments (Clavero et al. 2000, Niencheski $\&$ Jahnke 2002). The role of marine sediments as a source or sink for nitrogen is governed by the relative rates of several anaerobic and aerobic reactions. Concentration of different chemical species of nitrogen in sediment is mainly controlled by the rate of the following processes: ammonium production from organic matter (ammonification), nitrate production from ammonium 
oxidation (nitrification), anaerobic ammonium oxidation (anammox) to gaseous nitrogen, reduction of nitrate to ammonium (assimilative or dissimilative reduction) or to molecular nitrogen gas (denitrification) (Bange et al. 2005, Risgaard-Petersen et al. 2005, Francis et al. 2007). The ecological consequence of the latter is that nitrogen is unavailable to most of the producers such as phytoplankton and bacteria unless it is transformed into organic nitrogen during its fixation (An \& Gardner 2002, Bange et al. 2005). On the other hand, the coupled nitrification-denitrification activity is one of the few natural processes capable of removing nitrogen from coastal waters and of counteracting eutrophication (Macreadie et al. 2006).

Microbiological reduction of nitrate to ammonium occurs under anaerobic conditions and it is carried out predominantly by chemoheterotrophic bacteria (Sánchez \& Sanabria 2009). In this case, nitrate is used as terminal electron acceptor during the oxidation of organic compounds (Maier et al. 2000). This process can represent between $20-70 \%$ of the total reduction of nitrate, particularly in sediments with high organic matter content and a low oxidation-reduction potential (Esteves et al. 1986, Christensen et al. 2000, Sánchez \& Sanabria 2009). Inhibition of denitrification process reinforces the enrichment of nutrients in the water column allowing an increase in the ammonium recycled rate from sediment and favoring the development of primary production and retention of nitrogen in the environment (Christensen et al. 2000, Cabrita \& Brotas 2000).

Denitrification activity in sediment can be affected by temperature, $\mathrm{pH}$, dissolved oxygen, redox potential, nitrate and ammonium concentrations and organic matter content (Christensen et al. 2000, An \& Gardner 2002, Tomaszek \& Czerwieniec 2003). Increases in the temperature and $\mathrm{pH}$ (between 6 and 8 ) stimulate the nitrate reduction activity, while high ammonium concentration inhibits it. The measurement of nitrate reduction activity in sediments can be carried out using batch system methods which have the advantage of simplicity. However, in these methods the accumulation of metabolic compounds (e.g., ammonium) may inhibit denitrifying activity. On the other hand, the continuous flow-through sediment-water system allows that the metabolites formed during the process are continuously removed from the reactor, and thus do not disturb bacterial metabolic activity. The reactor represents a microcosm with some controlled variables that allow us to determine the kinetic constants to be used for estimate the natural functioning in Encerrada Bay.

The aim of the present study was to assess the in vitro nitrate reduction activity using a continuous flowthrough system in sediments from Encerrada Bay. Taking into account anoxic condition and the lack of nitrate and nitrite in pore water we expect to find a significant nitrate reduction activity in the superficial layer of sediment in this ecosystem.

\section{Materials AND Methods}

\section{Study Area}

Encerrada Bay (54 ${ }^{\circ} 48.9^{\prime} \mathrm{S}$; $\left.68^{\circ} 19.0^{\prime} \mathrm{W}\right)$, referred to hereafter as EB, is a semi-closed coastal system and it is located close to Ushuaia city in Tierra del Fuego province (Argentina) (Fig. 1). This bay has an area of $0.27 \mathrm{~km}^{2}$ and a mean depth of $0.8 \mathrm{~m}$. It is separated from Ushuaia Bay by artificial pathways, which communicate both Bays through two vents (P1 and P2 of $4.5 \mathrm{~m}$ long each), allowing water exchange in each semi-diurnal tidal cycle. EB has a high level of eutrophication due to the input of domestic and industrial wastewater through several discharges (Onas, Guaraní and Beban sewages and Buena Esperanza stream) from Ushuaia city. Although dissolved oxygen level in the water column remained close to saturation, Torres et al. (2009) observed anoxic sediment conditions, with predominantly black coloration and a brown thin layer $(<5 \mathrm{~mm})$ on the top of sediment in some sites of the bay, which is evidence that dissolved oxygen is incorporated only in this section. This suggests that coupled nitrification-denitrification could be restricted to that thin layer and only in some places of EB. Torres et al. 2009 also found average sediment porosity of $63.1 \pm 4.7 \%$, grain size below $63 \mu \mathrm{m}$, organic matter content between 8 and $19 \%$, ranges of pore water and total ammonium concentrations of 0.14-0.59 $\mu \mathrm{mol} \mathrm{cm}{ }^{-3}$ and 0.41-0.92 $\mu \mathrm{mol}$ $\mathrm{cm}^{-3}$ wet sediment, respectively and undetectable pore water nitrate concentrations (in accordance with negative values of redox potential). Benthic fluxes in the sedimentwater interface showed consumption of dissolved oxygen and nitrate by sediment and release of ammonium and phosphate into the water column (Torres et al. 2009). In such cases, when the available dissolved oxygen is not enough to oxidize the organic matter, nitrate is expected to be used as terminal electron acceptor. 
Figure 1. a) Map of the study area. b) Position of Buena Esperanza Stream (BES), Onas, Guaraní and Beban runoffs and vents (P1 and P2) that communicate to Encerrada and Ushuaia Bay. The three circles indicate the sampled sites in Encerrada Bays / a) Mapa del área de estudio. b) Posición de las descargas: Arroyo Buena Esperanza (BES), Onas, Guaraní y Beban y de las aberturas (P1 y P2) que comunican las Bahías Encerrada y Ushuaia. Los tres círculos indican los sitios muestreados en Bahía Encerrada
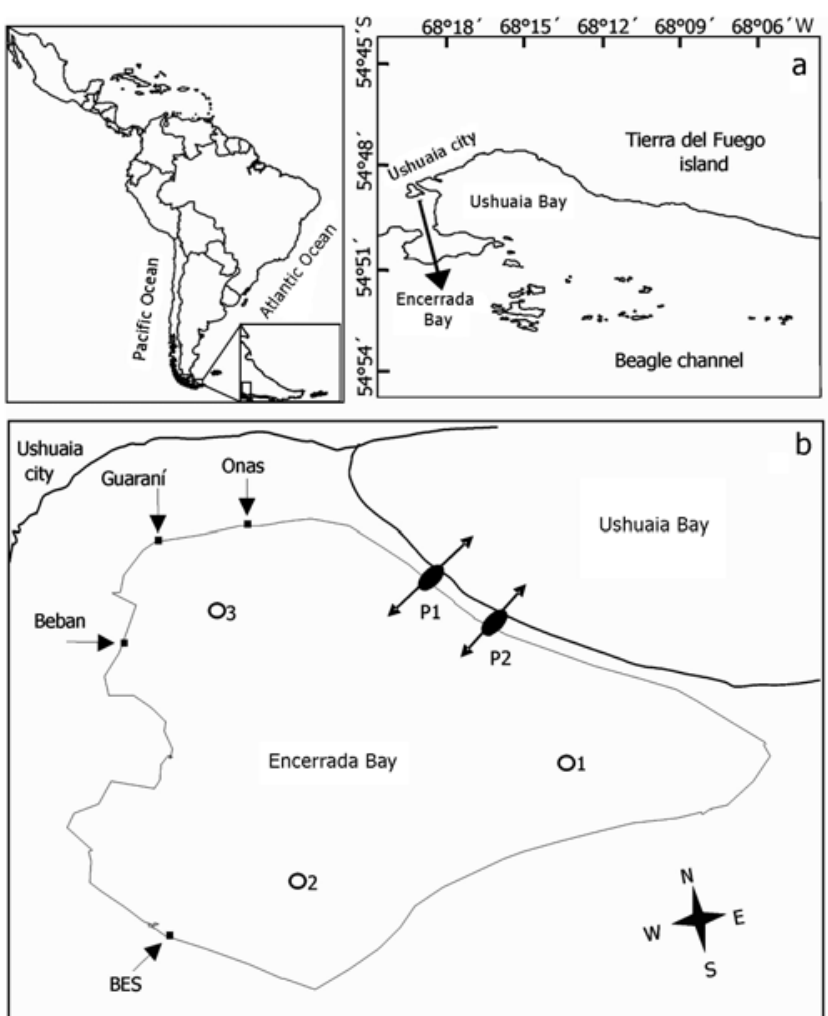

\section{SEDIMENT SAMPLING}

Sediment was collected at three stations in EB with a VanVeen dredge from a boat, in September 2007 (Fig. 1). The superficial layer $(<1 \mathrm{~cm})$ was separated on board using spatulas and then placed in hermetic plastic containers. A layer of $1 \mathrm{~cm}$ of seawater was added in situ and then stored at $4{ }^{\circ} \mathrm{C}$ in dark conditions until the beginning of experiences, within 10 days from sampling day. Immediately before the beginning of each experience, the three sediment samples were homogenized in an oxygenfree glove box, filled with an inert gas $\left(\mathrm{N}_{2}\right)$.

\section{NITRATE REDUCTION ACTIVITY DETERMINATION}

Nitrate reduction activity was measured in vitro using the continuous flow-through system method developed by Northby (1976) and adapted by Esteves et al. (1986) to microbiological processes (Fig. 2). The Northby's equation for a continuous flow-through system at time ' $\mathrm{t}$ ' can be written as:

$$
\left[J_{0} X_{i}(t)+R_{c}(t)\right]-\left[J_{0} X_{0}(t)\right]=\frac{d}{d t}\left[W \cdot X_{0}(t)\right]
$$

where $J_{0}$ : flow of initial seawater solution enriched with nitrate (in this study $\mathrm{KNO}_{3}$ was used) $\left(\mathrm{l} \mathrm{h}^{-1}\right) ; X_{i}$ and $X_{0 \text { : }}$ input and output nitrate concentrations $\left(\mu \mathrm{mol} \mathrm{l}^{-1}\right)$, respectively; $R_{c}$ : nitrate consumption $\left(\mu \mathrm{mol} \mathrm{h}^{-1}\right)$; and $W$ : dry weight of sediment in the reactor (g). In the steadystate the second member of the equation 1 is equal to zero and the nitrate reduction rate $\left(R_{c} N O_{3}^{-}\right)$, defined as function of the dry weight of sediment introduced into the reactor $\left(\mu \mathrm{mol} \mathrm{h} \mathrm{h}^{-1} \mathrm{~g}^{-1}\right)$ is obtained as follows:

$$
R_{c} N O_{3}^{-}=R_{c} / W=J_{0}\left(X_{0}-X_{i}\right) / W
$$

Negative values of $\left(\mathrm{R}_{\mathrm{c}} \mathrm{NO}_{3}^{-}\right)$correspond to nitrate uptake by microbial community.

\section{EXPERIMENTAL DESIGN}

Experiences were carried out by triplicate and different nitrate concentrations $(25,100,200,400 \mu \mathrm{M})$ were used. The seawater was filtered, enriched with nitrate and sterilized in autoclave during 20 min under 1.5 atmospheres to obtain low dissolved oxygen levels. Inside the reactor, the sediment ( $8.8 \pm 2.6 \mathrm{~g}$ dry weight) was retained on a 


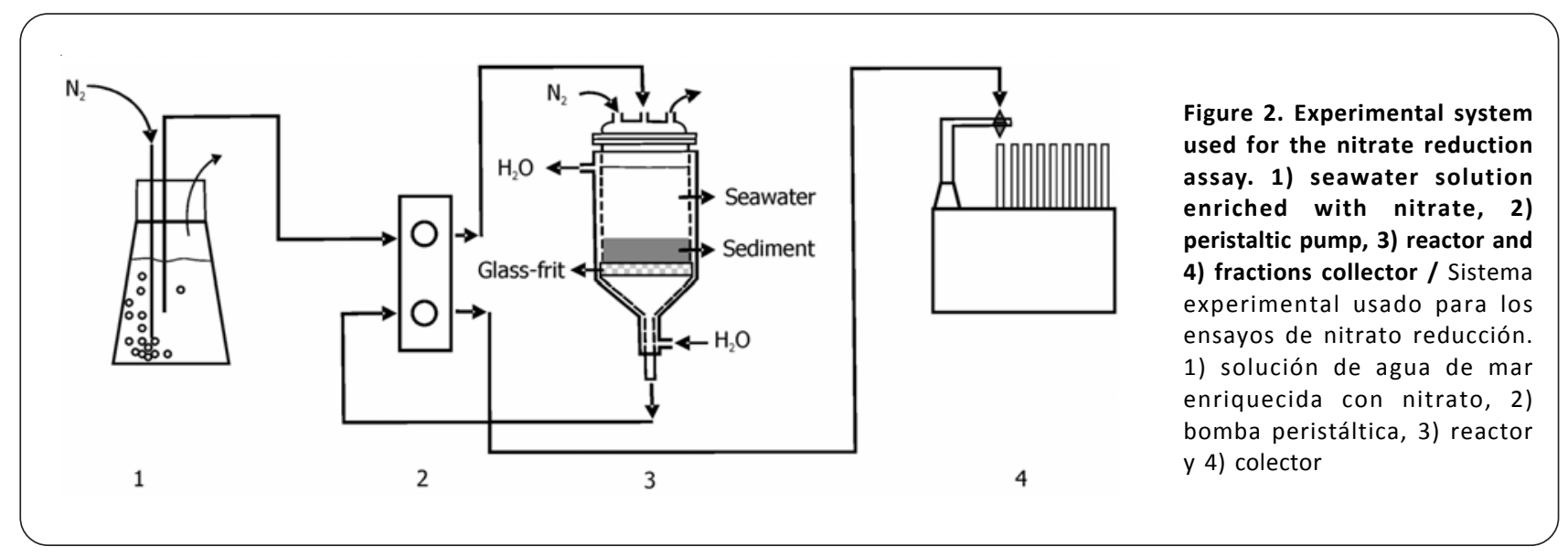

glass-frit (10 $\mu \mathrm{m}$ porosity). Low oxygen atmosphere was obtained by purging the system with nitrogen gas. A temperature of $17 \pm 1^{\circ} \mathrm{C}$ was maintained by water circulation around each reactor using a thermostatic bath (Mgw Lauda Kzr). We expected an increased nitrate reduction activity at that temperature in $\mathrm{EB}$, which is the typical summer value in seawater (Torres et al. 2009). The experiences were run in dark conditions in order to avoid the activity of photosynthetic microorganisms. Each reactor was supplied with enriched seawater at a constant flow (36 $\mathrm{ml} \mathrm{h}^{-1}$ ) through a Technicon peristaltic pump. The flow value was defined according to Esteves et al. (1986) and Montes (1994). The experiences lasted $9 \mathrm{~h}$. After the first $4 \mathrm{~h}$ (enough time to achieve stability of the system) and every $30 \mathrm{~min}$, a fraction of $15 \mathrm{ml}$ was taken from the reactor outflow. Immediately, ammonium concentration was measured in a subsample of $5 \mathrm{ml}$, according to Strickland \& Parsons (1972). The remaining volume was stored at $-20^{\circ} \mathrm{C}$ for determination of nitrate $\left(\mathrm{NO}_{3}^{-}\right)$and nitrite $\left(\mathrm{NO}_{2}^{-}\right)$concentrations following the Strickland \& Parsons (1972) methods modified by automatic process of Technicon ${ }^{1}$ (1977).

\section{KiNETIC CONSTANTS DETERMINATION}

The $\left(R_{c} N O_{3}^{-}\right)$values were plotted as function of initial nitrate concentration in the reactor and double reciprocal relationship between them was applied. The MichaelisMenten function was fitted to the data by least-square regression:

$$
V=V_{\max } \cdot X / K_{m}+X
$$

where $V$ : nitrate uptake rate $\left(R_{c} N O_{3}^{-}\right)\left(\mu \mathrm{mol} \mathrm{g}{ }^{-1} \mathrm{~h}^{-1}\right), V_{\max }$ :

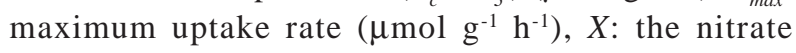
concentration $\left(\mu \mathrm{mol} \mathrm{l}^{-1}\right)$, and $K_{m}$ : half-saturation constant $(\mu \mathrm{M})$.

\section{RESULTS}

Nitrate concentration within each reactor increased until reaching the steady state nearly 300 min after the beginning of each experience (Fig. 3). Final value was always lower than that in the initial solution (between 9\% and $96 \%$ in the experiences $\mathrm{N}^{\circ} 10$ and 6, respectively), indicating a consumption of this ion. Similarly, nitrite concentration increased in each experience during approximately 330 min until stationary state (not shown), but reaching a final value that was higher than that in the inlet (from 0.5 to $92 \mu \mathrm{mol} \mathrm{l}^{-1}$ according to the treatment). This pattern suggests production of this ion as an intermediate compound during the nitrate reduction process (Table 1). On the other hand, ammonium in the steady state showed higher concentrations than those in the initial solution for each treatment (Table 1). The differences between initial and final concentrations ranged from 0.2 to $150 \mu \mathrm{mol} \mathrm{l}^{-1}$, suggesting a production of this ion.

The calculated nitrate reduction activities $\left(\mathrm{R}_{\mathrm{c}} \mathrm{NO}_{3}^{-}\right)$ ranged from -1.7 to $-0.012 \mu \mathrm{mol} \mathrm{g}^{-1} \mathrm{~h}^{-1}$ (Table 2). The relationship between $R_{c} N_{3}^{-}$and initial nitrate concentrations is presented in Fig. 4a, and double reciprocal relationship between those parameters in Fig. 4b. Nitrate uptake rates exhibited saturation kinetics, such

\footnotetext{
${ }^{1}$ Technicon. 1977. AutoAnalyzer II. Technicon Industrial Systems. Tarrytown, New York. 10591. Technicon Instruments Corporation.
} 

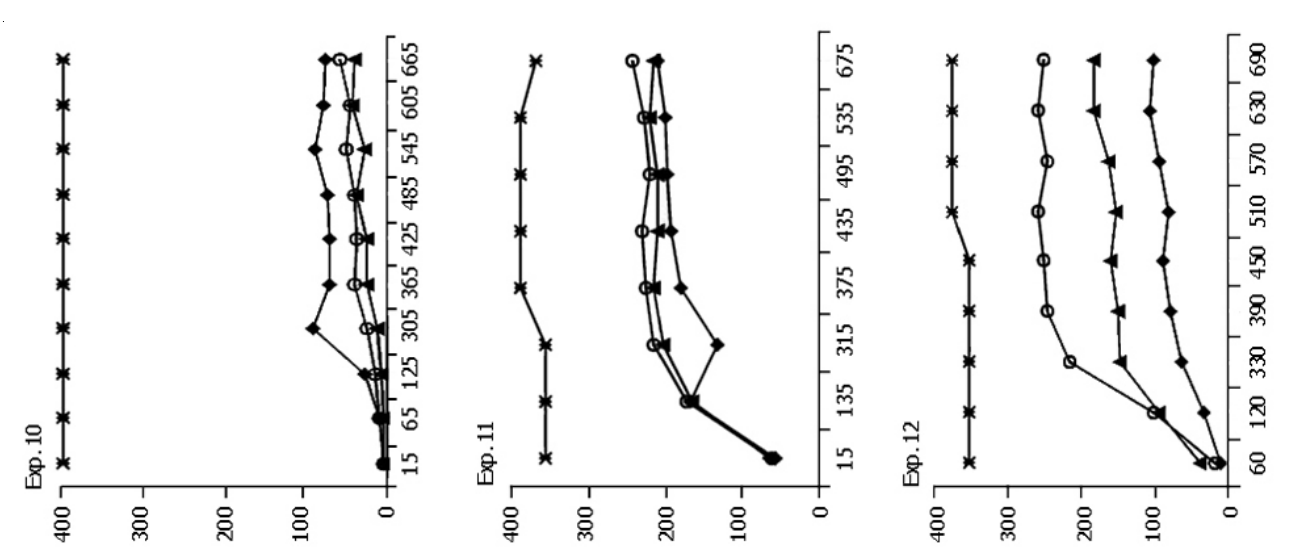

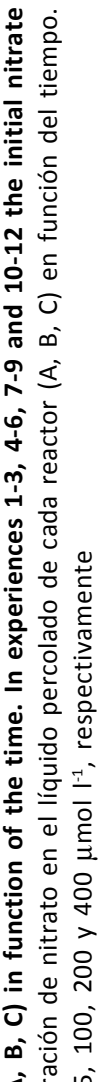
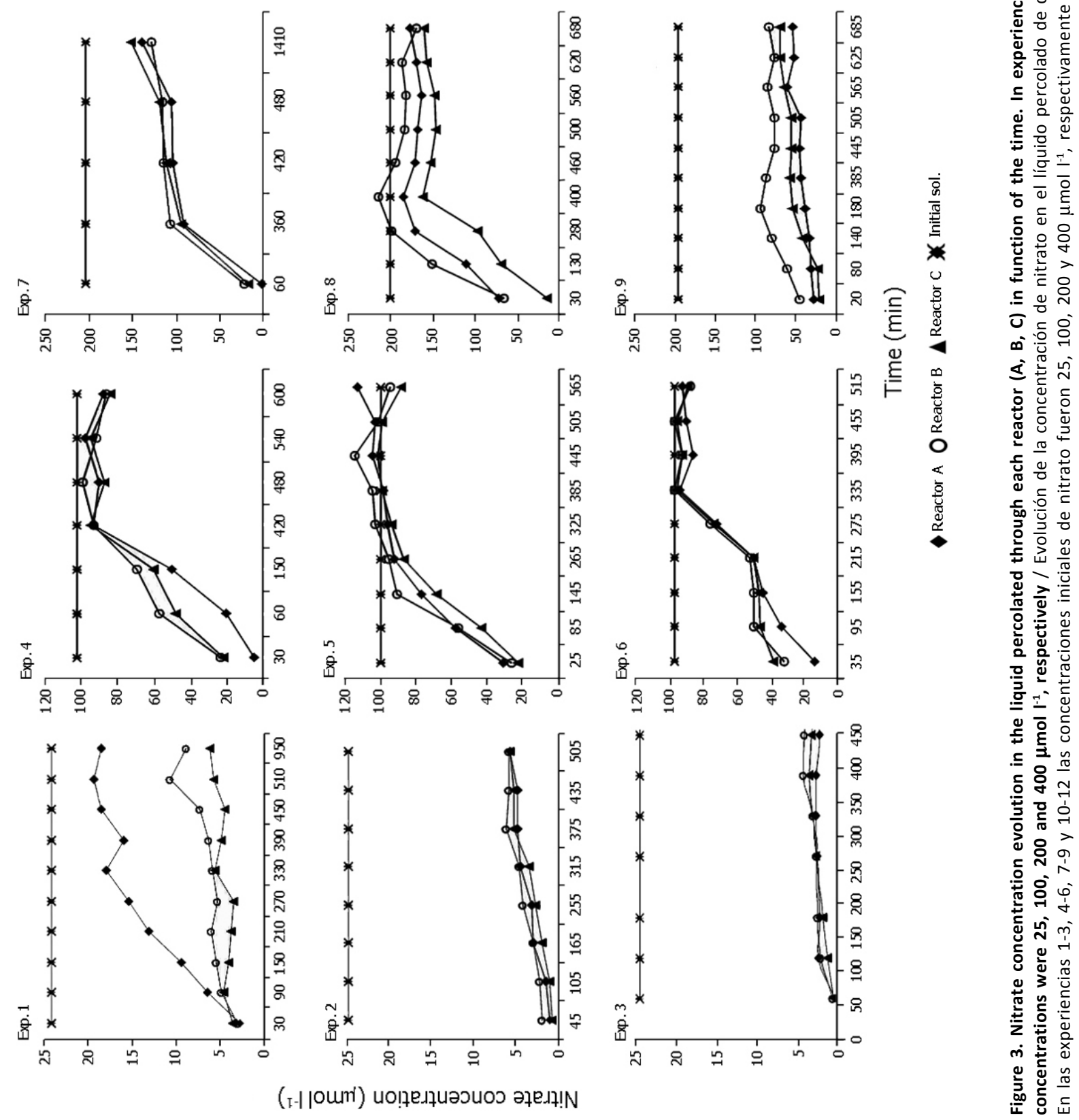

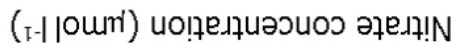




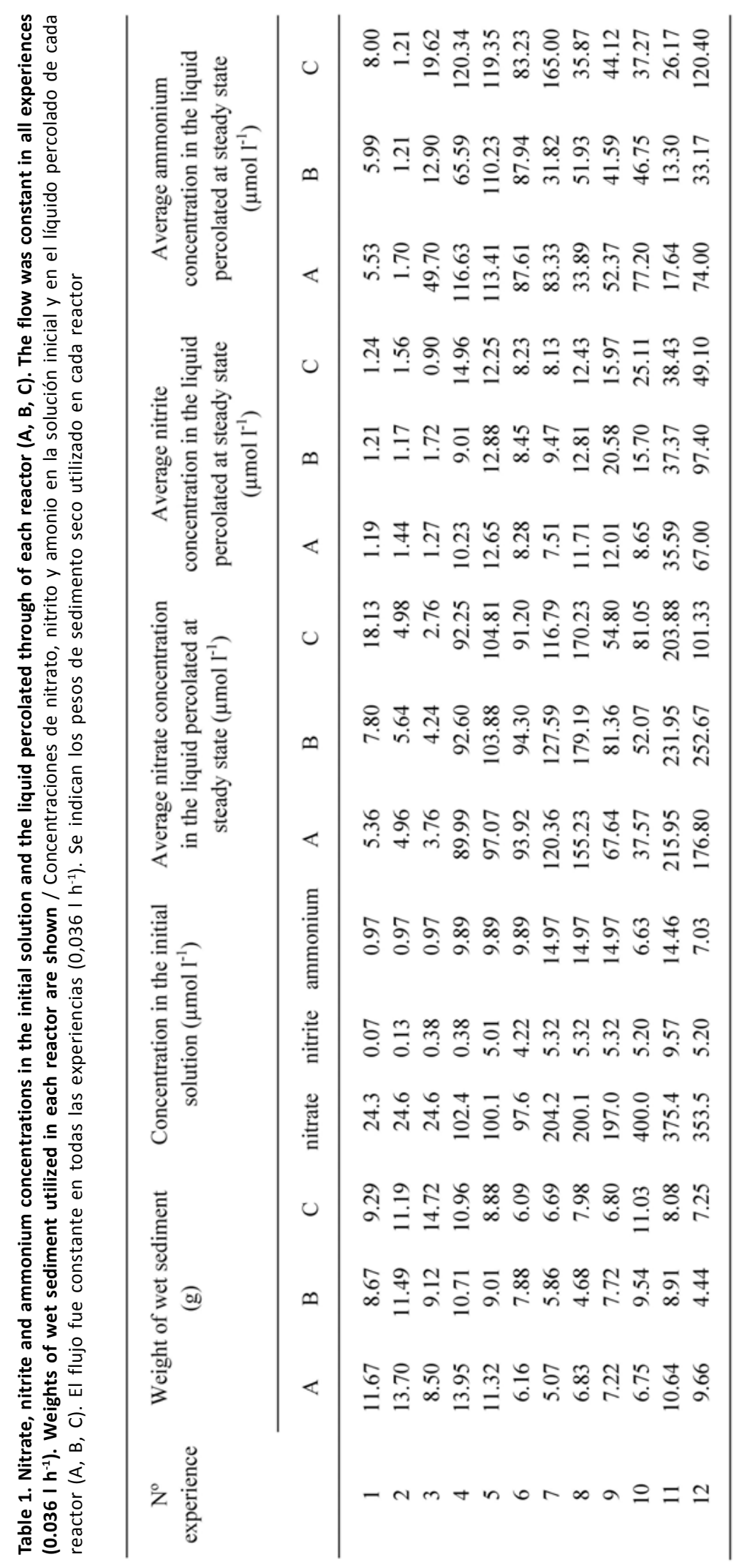


Table 2. Nitrate reduction activities $\left(\mathrm{R}_{c} \mathrm{NO}_{3}^{-}\right)$in each reactor $(A, B, C)$ estimated from in vitro experiences / Actividad nitrato reductora $\left(R_{c} N_{3}{ }^{-}\right)$en cada reactor (A, B, C) estimada a partir de las experiencias in vitro

\begin{tabular}{cccc}
\hline \multirow{2}{*}{$\begin{array}{c}\mathrm{N}^{\circ} \\
\text { Exp./reactor }\end{array}$} & \multicolumn{3}{c}{$R_{c} N O_{3}^{-}\left(\mu \mathrm{mol} \mathrm{g}^{-1} \mathrm{~h}^{-1}\right)$} \\
\cline { 2 - 4 } & $\mathrm{A}$ & $\mathrm{B}$ & $\mathrm{C}$ \\
\hline 1 & -0.073 & -0.068 & -0.019 \\
2 & -0.063 & -0.060 & -0.052 \\
3 & -0.051 & -0.081 & -0.093 \\
4 & -0.041 & -0.033 & -0.026 \\
5 & -0.012 & -0.015 & -0.015 \\
6 & -0.022 & -0.015 & -0.037 \\
7 & -0.451 & -0.471 & -0.620 \\
8 & -0.202 & -0.161 & -0.158 \\
9 & -0.685 & -0.539 & -0.709 \\
10 & -1.183 & -1.314 & -1.701 \\
11 & -0.711 & -0.579 & -0.581 \\
12 & -0.877 & -0.818 & -0.939 \\
\hline
\end{tabular}

as that predicted by the Michaelis-Menten model. Kinetic parameters obtained were $V_{\max }=2.7 \mu \mathrm{mol} \mathrm{g}{ }^{-1} \mathrm{~h}^{-1}$ and $K_{m}=$ $1028 \mu \mathrm{M}$.

\section{Discussion}

Nitrate reduction activity in anaerobic sediments represents an important alternative pathway as a source of electron acceptors for oxidation of organic matter (Sánchez \& Sanabria 2009). In environments with high eutrophication, as in EB, dissolved oxygen concentration is rapidly depleted in superficial layer of sediment. In deeper layers only restricted or facultative bacterial metabolisms can be involved in the degradation of organic matter. In spite of negative values of redox potential in sediment and the non detectable concentrations of nitrate and nitrite in pore water, high concentrations of both nitrogen compounds in water column of EB were measured (Torres et al. 2009). This fact suggests an intense bacterial activity that uses nitrate as terminal electron acceptor in the upper layer of sediment and no inhibition in nitrate reduction activity has been observed. Eventhough ammonium increase was observed, significance of dissimilative reduction of nitrate relative to denitrification, can not be assessed with this methodology.

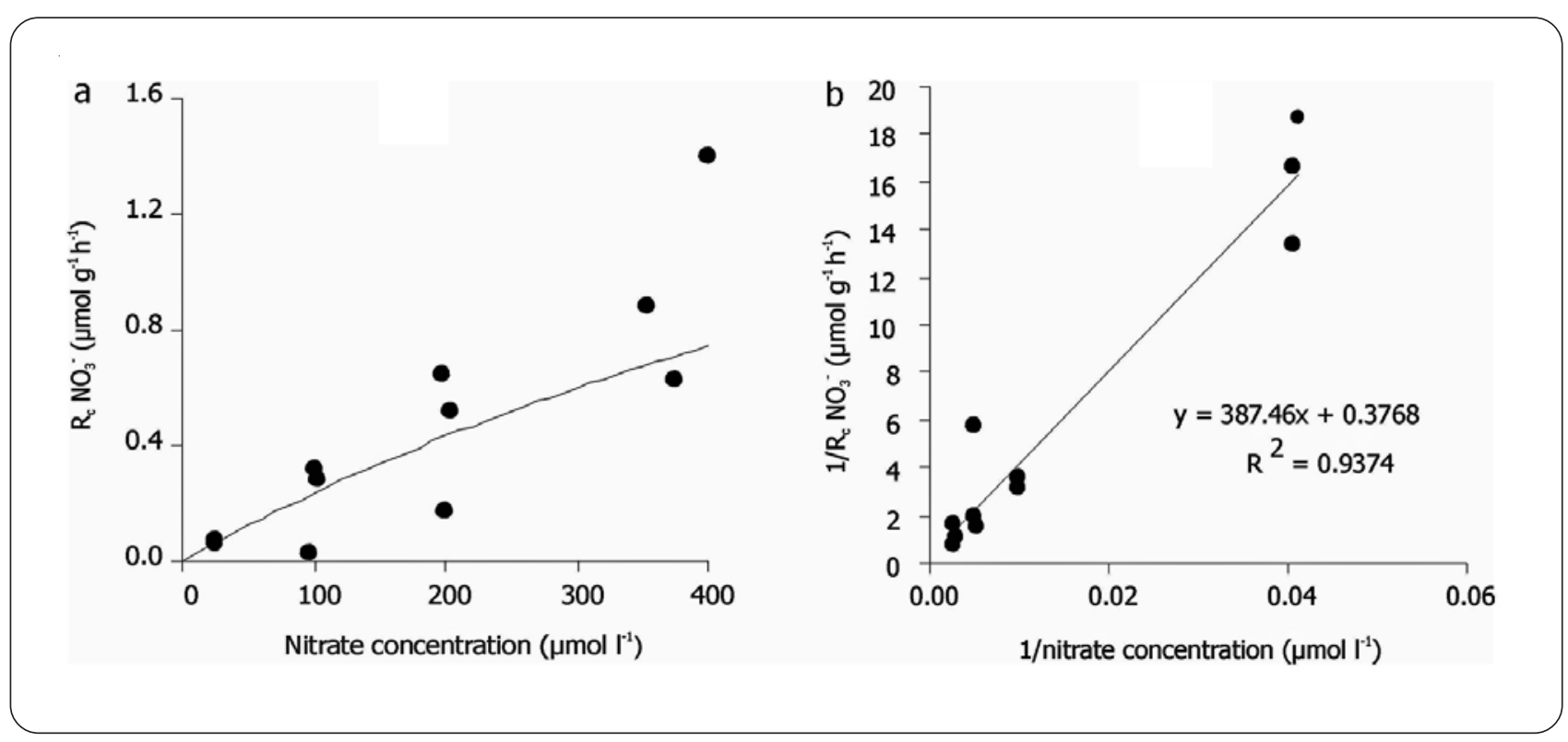

Figure 4. a) Nitrate reduction activity $\left(R_{c} \mathrm{NO}_{3}^{-}\right)$as function of initial nitrate concentration (black points); and curve was fitted by use of the Michaelis-Menten equation (line); b) Double reciprocal plot of the nitrate concentration vs nitrate reduction activity / a) Actividad nitrato reductora $\left(R_{c} N_{3}^{-}\right)$como función de la concentración inicial de nitrato (puntos negros); y la curva fue ajustada mediante la ecuación de Michaelies-Menten (línea); b) Doble recíproca de la concentración de nitrato vs la actividad nitrato reductora 
Kinetic parameters of nitrate reduction activity adjusted to Michaelis-Menten model were one or two orders of magnitude greater than those determined by Montes (1994) in coastal systems of low latitude in Argentinean Patagonia. This author determined in petroleum impacted sediments and with low organic matter content $(<$ $2 \%$ ) a maximum uptake rate $V_{\max }=25.6 \cdot 10^{-3} \mu \mathrm{mol} \mathrm{g}^{-1} \mathrm{~h}^{-1}$ and half-saturation constant $K_{m}=48 \mu \mathrm{M}$ at a temperature of $17^{\circ} \mathrm{C}$. Furthermore, Montes (1994) reported inhibition of this activity using a nitrate concentration of $500 \mu \mathrm{mol} \mathrm{l}^{-1}$. On the other hand, Esteves et al. (1986) found a $V_{\max }=168.0 \cdot 10^{-3} \mu \mathrm{mol} \mathrm{g}^{-1} \mathrm{~h}^{-1}$ and a half-saturation constant $K_{m}=78 \mu \mathrm{M}$ in sediments with organic matter content $<1 \%$ from Mediterranean Sea (France). The kinetic constants found in this study were in the same order of magnitude than those informed by An \& Gardner (2002) in sediments from Baffin Bay (Southern USA). However, the obtained parameters were lower than those determined by Jorgensen \& Sorensen (1988) in sediments of Norminde's fjord (Denmark) with organic matter content between 5-15\% and greater than those measured by Kaspar (1983) in intertidal sediments of New Zealand.

Keeping in mind the equation 3, and considering kinetic parameters obtained in this study, average density of sediment $\left(1.26 \pm 0.07 \mathrm{~g} \mathrm{~cm}^{-3}\right)$, and the range of variation of nitrate concentration in water column $(4-40 \mu \mathrm{M})$ measured by Torres et al (2009), it is possible to estimate in situ nitrate flux in the sediment-water interface by surface unit $\left(\sim 1 \mathrm{~m}^{2}\right)$. Assuming that total nitrate reduction in sediment of EB is restricted to superficial layer of $0.005 \mathrm{~m}$ we should expect nitrate fluxes between 66 and $637 \mu \mathrm{mol} \mathrm{m}^{-2} \mathrm{~h}^{-1}$. These values are in the same order of magnitude than fluxes obtained in situ through opaque benthic chambers (20 and $416 \mu \mathrm{mol} \mathrm{m}^{-2} \mathrm{~h}^{-1}$ ) in the same coastal environment (Torres et al. 2009). According to Kaspar (1983) and Enoksson \& Samuelsson (1987) denitrification process in several sediment types, including mud, marsh, sand and eelgrass bed, can represent between 70 and $95 \%$ of total nitrate consumption. In that case, for a nitrate flux of $637 \mu \mathrm{mol} \mathrm{m}^{-2} \mathrm{~h}^{-1}$, the amount of released molecular nitrogen in EB would be between 446 and $605 \mu \mathrm{mol} \mathrm{m} \mathrm{m}^{-2} \mathrm{~h}^{-1}$. This would produce a loss of this nutrient by the system of about 2728-3293 Kg N per month.

The employed methodology in this study, allowed us to estimate nitrate uptake rate and provides information about the use of nitrate as terminal electron acceptor in an eutrophic system; ammonium or molecular nitrogen production can not be adequately explained. This methodology can be applied easily in those environments in which the systems in situ are affected by strong marine currents, deep sea sediment or sewage discharges (MillerWay \& Twilley 1996). Other advantage of this method, in addition to good reproducibility and quickness, is the small amount of sediment required, which permits the treatment of a large number of samples and also can be applied on board (Esteves et al. 1986, Miller-Way \& Twilley 1996).

We conclude that in an eutrophic bay as EB, the system acts as a sink of nitrate. The nitrate flux from the water column to the sediment is significant and is used principally as terminal electron acceptor during the oxidation of organic matter. Further researches are required to quantify whether the reduced nitrate is used for ammonium production (dissimilative reduction) or molecular nitrogen production (denitrification), in order to get a better understanding of nitrogen cycling in this environment.

\section{AcKNowledgMenTs}

This research was supported by Agencia Nacional de Promoción Científica y Tecnológica (PICT-REDES 2002 No090) and GEF-UNDP Project ARG 02/G31. The authors wish to thank Dr. Oscar Amin, Dr. Laura Comoglio, Sr. Ricardo Sáenz Samaniego, and Dr. Adrián Schiavini for their help during the campaign. We are also grateful to Dr. Erica Giarratano for her help in improving the text. We also thank the three anonymous reviewers for their valuable suggestions on the manuscript.

\section{LITERATURE CITED}

An S \& WS Gardner. 2002. Dissimilatory nitrate reduction to ammonium (DNRA) as a nitrogen link, versus denitrification as a sink in a shallow estuary (Laguna Madre/Baffin Bay, Texas). Marine Ecology Progress Series 237: 41-50.

Bange HW, SWA Naqvi \& LA Codispoti. 2005. The nitrogen cycle in the Arabian Sea. Progress in Oceanography 65: 145-158.

Cabrita MT \& V Brotas. 2000. Season variation in denitrification and dissolved nitrogen fluxes in intertidal sediments of the Tagus estuary, Portugal. Marine Ecology Progress Series 202: 51-65.

Camargo JA \& AAlonso. 2006. Ecological and toxicological effects of inorganic nitrogen pollution in aquatic ecosystems: A global assessment. Review article. Environment International 32: 831-849. 
Clavero V, JJ Izquierdo, JA Fernández \& FX Niell. 2000. Seasonal fluxes of phosphate and ammonium across the sediment-water interface in a shallow small estuary (Palmones River, southern Spain). Marine Ecology Progress Series 198: 51-60.

Christensen PB, S Rysgaard, NP Sloth, T Dalsgaard \& S Schwaerter. 2000. Sediment mineralization, nutrient fluxes, denitrification and dissimilatory nitrate reduction to ammonium in an estuarine fjord with sea cage trout farms. Aquatic Microbial Ecology 21: 73-84.

Enoksson V \& MO Samuelsson. 1987. Nitrification and dissimilatory ammonium production and their effects on nitrogen flux over the sediment-water interface in bioturbated coastal sediments. Marine Ecology Progress Series 36: 181189.

Esteves JL, G Mille, F Blanc \& JC Bertrand. 1986. Nitrate reduction activity by continuos flor-through system in marine sediments. Microbial Ecology 12: 106-120.

Francis CA, JM Beman \& MMM Kuypers. 2007. New processes and players in the nitrogen cycle: the microbial ecology of anaerobic and archaeal ammonia oxidation. MiniReview. International Society for Microbial Ecology 1: 1927.

Jorgensen KS \& J Sorensen. 1988. Two annual maxima of nitrate reduction and denitrification in estuarine sediment (Norsminde Fjord, Denmark). Marine Ecology Progress Series 48: 147-154.

Kaspar HF. 1983. Denitrification, nitrate reduction to ammonium, and inorganic nitrogen pools in intertidal sediments. Marine Biology 74: 133-139.

Macreadie PI, DJ Ros, AR Longmore \& MJ Keough. 2006. Denitrification measurements of sediments using cores and chambers. Marine Ecology Progress Series 326: 49-59.
Miller-Way T \& RR Twilley. 1996. Theory and operation of continuous flow systems for the study of benthic-pelagic coupling. Marine Ecology Progress Series 140: 257-269.

Montes MA. 1994. Efectos del petróleo sobre la nitratoreducción en sedimentos marinos. Tesis de Licenciatura en Ciencias Biológicas, Facultad de Ciencias Naturales, Universidad Nacional de la Patagonia San Juan Bosco, Puerto Madryn, 105 pp.

Niencheski LF \& RA Jahnke. 2002. Benthic respiration and inorganic nutrient fluxes in the estuarine region of Patos Lagoon (Brazil). Aquatic Geochemistry 8: 135-152.

Northby JA. 1976. A comment on rate measurements in open systems. Limnology and Oceanography 21: 180-182.

Risgaard-Petersen N, RL Meyer \& NP Revsbech. 2005. Denitrification and anaerobic ammonium oxidation in sediments: effects of microphytobenthos and $\mathrm{NO}_{3}{ }^{-}$. Aquatic Microbial Ecology 40: 67-76.

Sánchez J \& J Sanabria. 2009. Microbial metabolisms over advanced processes for Nitrogen removal, a prospective review. Revista Colombiana de Biotecnología 11(1): 114124.

Strickland JDH \& TR Parsons. 1972. A practical handbook of the seawater analysis. Fisheries Research Board of Canadá, Bulletin 167: 1-310.

Tomaszek JA \& E Czerwieniec. 2003. Denitrification and oxygen consumption in bottom sediments: factors influencing rates of the processes. Hydrobiologia 504: 5965.

Torres AI, MN Gil, O Amin \& JL Esteves. 2009. Environmental characterization of a eutrophicated semi-enclosed system: nutrient budget (Encerrada Bay, Tierra del Fuego Island, Patagonia, Argentina). Water Air and Soil Pollution 204: 259-270.

Received 19 November 2011 and accepted 4 May 2012

Associate Editor: Gabriela Muñoz C. 